\title{
The Verse Novel and Don Juan as a Vehicle for Satire
}

\begin{abstract}
This article argues that the choice of the hero in Lord Byron's Don Juan has two major consequences for satire. First, it allows the narrator to digress from the actual story, since the reader is supposed to be acquainted with Don Juan's fate. Second, Don Juan's iconic figure essentially stands for a particular quality, and it can be filled with arbitrary content. Byron uses this to put Don Juan into diverse roles, through which a multilevel satire emerges. The language of satire is dependent on a non-identificational mode, which is intertwined with Don Juan's status as a collector of roles he does not identify with. The heroes of subsequent verse novels are often epigones of Don Juan, yet for them this is typically just another role that they identify with only temporarily. The embedding of Don Juan as a possible role in later verse novels results in an embedding of the satirical mode: these texts are less sharp in their satirical aspects than Don Juan, and the field affected by their satire is more restricted. Further, the role "Don Juan" and the overarching satirical mode may also be subject to ironic treatment: later texts not only follow, but also question the Byronic stance.
\end{abstract}

Keywords: Byronic hero, digression, narrative structure, Romanticism, satire, verse novel

\section{Introduction}

From a cross-cultural point of view, Lord Byron's Don Juan can be considered the first verse novel (see the arguments in Bacskai-Atkari [2016]). Where nineteenth-century English literature is concerned, however, Don Juan belongs to the tradition of the Romantic verse narrative in the sense of Fischer (1991); ${ }^{1}$ thus, the verse novel was not established as a genre in English literature in the nineteenth century (Bacskai-Atkari 2016, 2017). The term "verse novel” or "novel in verse" stems from Pushkin, who defined his Eugene Onegin as such ("Роман в Стихах") in its subtitle. In Pushkin's case, this was an idiosyncratic subtitle indicating a certain closeness to the Russian prose novel (see Tosi [2006] on the connection). Later, the term "verse novel" emerged as a genre designator with the cross-cul-

1 This includes the connection to the mock epic, on which see Rawson (1990) and Cronin (2011).

2 Open Access. (c) 2021 Julia Bacskai-Atkari, published by De Gruyter. (c) BY-NC-ND This work is licensed under the Creative Commons Attribution-NonCommercial-NoDerivatives 4.0 International License. 
tural spread of relevant examples in world literature, ${ }^{2}$ whereby the verse novel came to be a well-established genre in certain national literatures, for instance in Hungarian literature (Bacskai-Atkari 2016). Interestingly, there are several contemporary verse novels written in English, such as Anthony Burgess's Byrne (see Addison [2009] on the phenomenon). In this way, the verse novel has established itself as a genre in English literature too (Bacskai-Atkari 2017).

While individual verse novels may differ from each other considerably, there are several characteristics that can be considered as prototypical features of the verse novel; the foregrounding of the narrator, the reflexive narrative structure, and the ironic/satirical mode can be mentioned here. Naturally, the formal characteristics of Byron's text had a significant impact on the formal characteristics of subsequent verse novels. However, the fact that Byron chose Don Juan as the hero raises at least two important questions. First, it should be considered whether the choice of the hero is essential to satire, that is, whether there is an inherent link between the character and the satirical mode and content of Don Juan. ${ }^{3}$ Second, the question arises of whether the character in Byron's Don Juan (that is, this particular instantiation of the legendary character) had an influence on later verse novels that have different heroes.

In this article, I propose that there is an interesting correlation between the Don Juan-like character of the hero in verse novels and the extent to which satire can be detected in them, one that involves the linguistic properties of the text. First, I will show that the choice of Don Juan as a hero in Byron's text is presented as an arbitrary decision of the narrator, and that the hero is secondary to the presence of the narrator; this contributes to a strongly reflexive text with a dominant narrator, whereby the linguistic and literary properties of the text are also topicalized. Second, the choice of Don Juan means a choice of a character who is familiar to the reader and who embodies certain qualities; this allows the narrator to place the hero in diverse roles in several contexts, resulting in a multilevel satire. Third, in later verse novels the role of Don Juan appears as one possible role; Don Juan thereby becomes both a vehicle and the target of satire.

2 National literatures vary regarding whether and to what extent the Byronic verse novel appeared in them. There are several examples from Polish and Hungarian literature (see, for instance, Modrzewska [2004] on the impact of Byron on Polish literature).

3 The present article cannot investigate the details of how satire is instantiated in Byron's Don Juan, but there are several studies devoted to detailed analysis of the question. See, for instance, Gregory (2013) and Cochran (2013a) for a comparative analysis involving the literary antecedents of the kind of satire found in Byron's work, and Shears (2013) for a detailed analysis of Cantos 1 and 2 in this respect. 


\title{
2 Byron's verse novel
}

The status of the hero in Don Juan is already topicalized at the very beginning of the text. Consider:

\author{
I WANT a hero: an uncommon want, \\ When every year and month sends forth a new one, \\ Till, after cloying the gazettes with cant, \\ The age discovers he is not the true one; \\ Of such as these I should not care to vaunt, \\ I'll therefore take our ancient friend Don Juan, \\ We all have seen him in the pantomime \\ Sent to the devil, somewhat ere his time. (Byron 1986 [1819], 1.1)
}

The narrator's persona dominates the text, and his presence is expressed earlier than his alleged choice of hero. Moreover, the narrator's rhetoric suggests that Don Juan is merely a last-resort option: the narrator needs a hero (any hero), primarily because there is no story to be told without one. Hence, in addition to the specific topic of Don Juan's life, a certain attitude is outlined in the very first stanza.

The choice of Don Juan as a hero has various implications that are either hinted at by the narrator at this point or can be deduced from how the story of Don Juan is handled. First, the choice of Don Juan is merely one possibility among several others (many of these are enumerated in stanzas 2-5 of Canto 1). Second, Don Juan is well known to the readers (maybe too much so) from popular genres as well, so the hero's story and eventual fate are not new. Third, the narrator has more freedom regarding Don Juan: the story is not only known but also flexible, as Don Juan is a legendary but still fictional character, as opposed to the historical personalities mentioned in stanzas 2-5.

Indeed, the narrator's comment that Don Juan's legend was well known to the contemporary reader can be verified historically, as was done by Haslett (1997): in addition to famous examples like Tirso de Molina's play El burlador de Sevilla y convidado de Piedra [The Trickster of Seville and the Stone Guest], Molière's play Dom Juan ou le Festin de pierre [Dom Juan, or The Feast with the Statue], or the opera Don Giovanni by Lorenzo da Ponte (libretto) and Wolfgang Amadeus Mozart (music), there were various theatrical versions and performances in Byron's period. The individual versions may differ considerably from each other, but one fixed point of the Don Juan story is that the hero goes to hell at the end. This fixed (and therefore commonly known) point is referred to in the quotation above. Otherwise, Don Juan embodies certain qualities more than he is tied to specific elements of a story: he is a womanizer, essentially young and wealthy, and a libertine who is apparently able to seduce all women. The fixed ending stands 
as a punishment for these qualities, and there is relative freedom in how these qualities are depicted through his actions.

Where Byron is concerned, it is evident that his text concentrates on the development of Don Juan into a seducer and on his adventures in this period of his life. In this way, the focus deviates from the established norm. The plans concerning the length of Don Juan, as expressed by the narrator, vary constantly (see Ackermann 1901, 150) and the end is postponed: the structure essentially allows for infinite continuations, suggesting that there is in fact no specific underlying plan (see Bacskai-Atkari 2008, 45-89; see also Christensen 1993, 215; Manning 1998, 183). Note that, in addition to this structural peculiarity, the text was not finished due to Byron's death, so the lack of the expected ending is also due to external factors.

Apart from the shift in focus in terms of Don Juan's life, it must be mentioned that Don Juan is often neglected by the narrator in favour of other topics. In this sense, Don Juan is used as a vehicle for satire. This naturally results in the narrator creating distance from the hero, which is in line with the non-identificational mood that can generally be observed in the text. Don Juan is placed in various countries and situations, which can thus be observed through him. Don Juan constantly reflects on the contemporary world (see McGann 2002, 38-45), resulting in a multilevel satire that targets contemporary society and some prominent members thereof, as well as extending to specific literary trends and modes of expression. In addition, due to the dominant status of the narrator and his frequent digressions (see McGann [1968, 278] and Stabler [2002, 3] on the central role of digressions), satire is not restricted to the depicted events of the story: it can also be observed in the narrator's remarks that point outside the text and address its readership or parts thereof. This generates a constant interaction with readers, ${ }^{4}$ especially with Byron's contemporaries, who were partly targeted by the satirical representations in the text. Byron's Don Juan has thus a markedly synthesizing character: as discussed by McGann (2002, 80-86), Byron practically condenses

\footnotetext{
4 Interaction with readers is, of course, not necessarily bound up with a satirical mode. For instance, the relationship between the poetic persona and the reader is foregrounded in Byron's Childe Harold as well, yet the narrator of the latter gives instead the impression of wishing to inform his readers (see Vulliamy 1948, 84); this is especially true in the case of contemporary Greece (see Marchand 1971, 94; Elledge 1998, 124-125). Further, he refrains from expressing critical views towards people who are at the same time taken to be parts of his audience. However, the connection with the reader is less explicit than in Don Juan. As established by Barton (1992, 79), the noun reader is not present in the text of Childe Harold, yet, as Stabler $(2002,77)$ points out, this is true only for the parts written in verse but not for the notes. In comparison to Don Juan, the dialogue with the reader is backgrounded (confined to the notes) and essentially not polemical.
} 
all of his life and previous works into the text; this also includes a "cumulative effect" (Reiman 1972, 1779) in which the meaning of the text is enriched by the accumulation of previous interpretations and reception. Indeed, Byron frequently refers to the reception of his works and engages in related debates with his hypothetical readers.

The story of Don Juan takes place in several locations, including Spain, Greece, Turkey, Russia, and England. All the scenes include social satire, albeit to varying degrees; in addition, satire does not necessarily target the particular land in which a scene is set: for instance, many elements in Canto 1, which is set in Spain, are reminiscent of Byron's England. The satirical mood of Don Juan is most explicit when Don Juan is placed in England (see Gregory 2013, 144-146). For instance, he has very high expectations of the country, which are contrasted with his first experience there (he is robbed by a mugger).

What is important for the present discussion is that the choice of Don Juan as a hero is in line with the text's aim of providing a multilevel social satire and with its highly reflexive narrative structure: Don Juan can be backgrounded and, as he is an adventurer, he can appear in various social contexts as well.

\section{Don Juan as a role}

Without discussing the differences from Byron's literary predecessors, let us provide an overview of the features of Byron's Don Juan and their effect on the heroes of subsequent verse novels. On the one hand, Don Juan is, like many of Byron's heroes, characterized by spleen: he is essentially lonely and disillusioned, and he experiments with several roles without truly identifying with any of them. It is important to note here that the opportunity of true love is lost, as described in the Haidée episode in Cantos 2-4 (see Barton [1998] on the importance of this love in Don Juan's life). Don Juan falls in love with Haidée, but her father returns and captures Don Juan as a slave and Haidée dies of despair. On the other hand, Don Juan is also a seducer: this follows from the legend, but there is no complete overlap with the legendary icon. More precisely, Byron's Don Juan does not actively attempt to seduce all the women he encounters: instead, he is able to fall in love (Haidée), he can be seduced (as by Donna Julia at the very beginning, when he is still inexperienced), and he can even refuse a woman's advances (as with Gulbeyaz, at least initially). His first amorous encounter is with Donna Julia, who is a few years older than him; Donna Julia initially treats Don Juan as a child, but, as time goes by, her feelings change, as indicated by the following description (and the subsequent stanzas): 
Juan she saw, and, as a pretty child,

Caress'd him often, such a thing might be

Quite innocently done, and harmless styled,

When she had twenty years, and thirteen he;

But I am not so sure I should have smiled

When he was sixteen, Julia twenty-three;

These few short years make wondrous alterations,

Particularly amongst sun-burnt nations. (Byron 1986 [1819], 1.69)

The narrator at this point stresses the innocence of Don Juan and makes Donna Julia appear as the actual seducer, which is reinforced by the rest of the canto. This kind of presentation contrasts with other versions of the Don Juan story, where Don Juan already appears as a confident and experienced seducer. Hence, the focus of the verse novel is on the development of Don Juan into a seducer; moreover, the text also describes how Don Juan's spleen develops, since this is not given at the beginning of the story either. Interestingly, in Don Juan's case, spleen appears prior to his development into a seducer: his spleen appears after the loss of Haidee and grows stronger during his adventures, even though those adventures are still indicative of his early stage as a seducer. That is, his spleen is not a result of his disillusionment with a former adventurous lifestyle.

The features of the heroes of prototypical verse novels are similar, yet there are some important differences. On the one hand, the hero of a verse novel is characterized by spleen: he is essentially lonely and disillusioned. Again, the opportunity of true love is lost, which is often the fault of the hero (as is the case with Eugene Onegin, who does not take Tatiana seriously; see the discussion below). On the other hand, the hero experiments with several roles without truly identifying with any of them, and one of these roles is that of Don Juan, whereby the role of Don Juan may evoke the legendary seducer figure and/or be similar to Byron's instantiation of Don Juan. Unlike in Byron's Don Juan, the appearance of spleen usually follows the seductive period: the hero is disillusioned with his previous lifestyle, and spleen entails a breakaway from amorous adventures.

It is also important to discuss the attitude of the narrator towards the hero: in general, verse novels demonstrate both similarities between the narrator and the hero and a critical stance on the narrator's part. Byron's narrator essentially adheres to Don Juan's character: he indicates at various points in the text that he has also had some similar adventures (especially regarding women), and he shares Don Juan's spleen. By contrast, subsequent verse novels are usually more critical with respect to "Don Juan-like" behaviour.

The first verse novel following Don Juan is Aleksandr Pushkin's Eugene Onegin (1825), which contains several explicit references to Byron. For instance, there is an explicit discussion of dark Romantic, Byronic heroes in relation to Tatiana's 
readings and feelings (chapter 3, stanza 12). An early example of a reference to Byron occurs when Onegin's spleen is compared to Childe Harold:

The illness with which he'd been smitten

should have been analysed when caught, something like spleen, that scourge of Britain, or Russia's chondria, for short; it mastered him in slow gradation; thank God, he had no inclination to blow his brains out, but instead to life grew colder than the dead. So, like Childe Harold, glum, unpleasing, he stalked the drawing-rooms, remote from Boston's cloth or gossip's quote; no glance so sweet, no sigh so teasing, no, nothing caused his heart to stir, and nothing pierced his senses' blur. (Pushkin 2003 [1825], 1.38)

At the same time, the narrator claims that his methods are (partly) different from those of Byron, and this difference is unambiguously taken to be positive:

O flowers, and love, and rustic leisure, o fields - to you I'm vowed at heart. I regularly take much pleasure in showing how to tell apart myself and Eugene, lest a reader of mocking turn, or else a breeder of calculated slander should, spying my features, as he could, put back the libel on the table that, like proud Byron, I can draw self-portraits only - furthermore the charge that poets are unable to sing of others must imply the poet’s only theme is "I." (Pushkin 2003 [1825], 1.56)

The tone and foregrounding of the narrator are reminiscent of Byron, yet the connection is viewed critically by Pushkin's narrator, who follows (partly) different principles of poetic composition. The dichotomy of following and criticizing Byron is not reduced to the linguistic and/or literary properties of the text but can also be detected where the hero is concerned. ${ }^{5}$ The disillusioned Onegin is

5 This can in fact be observed in Pushkin's poetry more generally. As described by Cochran (2013b, 199-202), Pushkin first encountered Byron in 1820 (in French translation), and Byron's 
an outsider in many respects and views contemporary society in a critical way. This contributes to the satirical elements of the text, which target St Petersburg society in particular and, to a lesser extent, village social life. While Pushkin offers a broad perspective, the overarching satirical mode characteristic of Byron is reduced considerably, especially when it comes to parody targeting people or phenomena outside the text. The language of Eugene Onegin, similarly to Byron's text(s), is highly self-reflexive and ironic, and the narrator has a dominant role.

The hero, Onegin, has Don Juan-like traits in both settings of Eugene Onegin: he appears as a seducer in St Petersburg, and he acts as a seducer in the countryside later when he pretends to be seducing Olga. However, Don Juan is only a role for him, one with which he cannot identify fully, and this is evident in both contexts. Onegin's spleen emerges towards the end of his St Petersburg period, as a result of his disillusionment with being a seducer. In the countryside, he only takes up the role of a seducer once, but this has a different purpose. He does not actually want to seduce Olga; he merely wants to reveal her true character for her fiancé Vladimir Lensky, who is his friend; this experiment results in a disaster, since the offended Lensky demands a duel in which Onegin shoots him dead. In sum, Don Juan is a clearly identifiable role in Eugene Onegin, but it is only temporarily present, and it is viewed critically, just like Byron's overarching satirical stance.

Let us now turn to another verse novel. Anthony Burgess's Byrne (published in 1995) explicitly starts with a comparison between the narrator and Byron, and between Byrne and Don Juan (see Bacskai-Atkari 2017):

He thought he was a kind of living myth

And hence deserving of ottava rima,

The scheme that Ariosto juggled with,

Apt for a lecherous defective dreamer.

He'd have preferred a stronger-muscled smith,

Anvilling rhymes amid poetic steam, a

Sort of Lord Byron. Byron was long dead.

This poetaster had to do instead. (Burgess 2002 [1995], 1.1)

Importantly, unlike in Pushkin's case, the difference from Byron is viewed negatively here, and Burgess's narrator explicitly claims that he is a lesser-skilled poet than Byron was.

influence can be detected in A Prisoner of the Caucasus (1820) and in The Fountain of Bakhchisarai (1821-1822). On the one hand, there are various non-Byronic features, particularly in The Fountain of Bakhchisarai; on the other hand, it is evident from Pushkin's correspondence that he was dissatisfied with the idea of being an inadequate plagiarist of Byron (Cochran 2013b, 199-200). 
Byrne is fairly similar to Don Juan: he is a womanizer and an adventurer, and he travels extensively, just like Byron's Don Juan. However, the similarity is not accidental: Byrne is essentially an epigone of Don Juan. In other words, Don Juan is again a role that the hero uses, though in this case not just on a temporary basis, for Byrne embeds this quality into his general tendency of playing with masks (including names); hence, this role is part of his self-representation. Satirical elements can be detected in the text, but the hero serves less as a vehicle for them than Don Juan does: Burgess's text essentially aims at establishing the legendary character of Byrne, while Byron demystifies the character of Don Juan. In line with this, the role of spleen is also reduced: Byrne does not seem to develop with time.

To take another modern example, Vikram Seth's The Golden Gate (1986) features the protagonist John Brown, an IT expert, who is past his womanizing phase, as is evident from the introductory description of him:

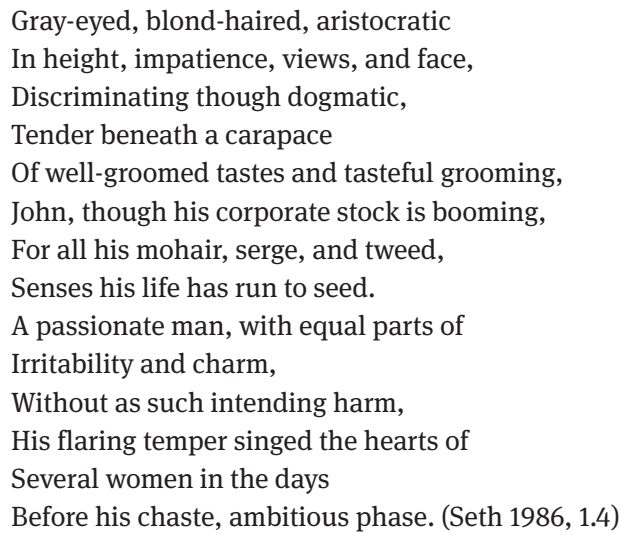

Altogether, John is only remotely similar to Don Juan apart from his past hinted at in the stanza quoted above. His experiments with relationships (Liz, Janet) described in the verse novel serve instead to find true love, and they cannot be viewed as instances of seduction. The lack of Don Juan as a role makes the narrative more condensed: the hero does not seek adventures or travel extensively. In line with all this, satirical elements are barely present, the primary focus of the text being on love and on a circle of family and friends. Moreover, the narrator is not as dominant as in Byron's verse novel, and the text is altogether less self-reflexive.

Finally, let us consider a further international example, namely János Térey's Paulus (2001). It is strongly based on Pushkin's Eugene Onegin. The protagonist, Pál, is an IT expert: he is a system administrator and hacker at the same time, which is a prime example of the question of a double-sided nature generally 
present in the work. Beyond the level of the story, the dichotomy is also relevant in terms of composition: the text both imitates Pushkin's synthesizing approach and questions it (see Margócsy 2002). The same relation was observed between Byron's Don Juan and Pushkin's Eugene Onegin above: in this sense, Térey's verse novel is a critical reinterpretation not only of Pushkin's text but also, indirectly, of Byron's text.

The protagonist is similar to Don Juan in that he is a womanizer. However, this is only one role for him among other ones that he experiments with in his general dichotomy of building and destroying. Pál's satirical stance is viewed critically by the narrator, and there is no overarching satirical mode in the sense that the satirical viewpoint is also thematized and questioned. In line with this, the language is mixed and is characterized by juxtapositions, and the text is highly self-reflexive.

The verse novels discussed in this section all have heroes who are reminiscent of Byron's Don Juan, though to varying degrees. Importantly, Don Juan is taken as a hero by Byron not least because he can be used as a vehicle for (social) satire, for his story can occasionally be backgrounded in favour of other topics. This configuration is modified by later verse novels, in which the model of Don Juan is taken to be one of various possible roles for the hero. In this sense, the role of Don Juan is evaluated critically, too, and the overarching satirical mode is less prominent, as the focus is shifted towards more individual levels. The critical stance is strongest in the case of Pushkin's Eugene Onegin and Térey's Paulus, whereby the latter example is characterized by fragmentation and thus hinders the possibility of an overarching satirical stance. By contrast, there is no criticism in Burgess's Byrne, where the hero is presented as an epigone of Don Juan. Criticism is indirect in Seth's The Golden Gate, in that the seducing period of the hero is over and it is implied that his quest for true love, as well as the characters' attempts at establishing families, is superior. In sum, it appears that relating to Don Juan is important in various verse novels, irrespective of whether and to what extent they adhere to the Byronic novel.

\section{Conclusion}

In this article, I have examined the choice of Don Juan as a hero in Byron's Don Juan and its consequences for the genre of the verse novel. I have argued that choosing Don Juan enables a highly self-reflexive, digressive mode of narration, not the least due to the familiarity of the hero for the reader. Furthermore, this choice enables a flexible handling of the story: essentially, the legend has only a few fixed points and the gaps can be filled with arbitrary content. This flexibil- 
ity makes a multilevel satire possible in Byron's Don Juan, since the hero can be placed in various contexts and the narrator is also allowed to digress extensively. The consequence for later verse novels is that both the figure of Don Juan and the satirical mode of narration serve as models, but both tend to be embedded alongside other concerns, and their validity may be questioned.

\section{Works cited}

Ackermann, Richard. Lord Byron. Heidelberg: Winter, 1901.

Addison, Catherine. “The Verse Novel as Genre: Contradiction or Hybrid?” Style 43.4 (2009): 539-562.

Bacskai-Atkari, Julia. “The Ironic Hero: Narration in Lord Byron’s Don Juan.” Első Század 2008.1 (2008): 45-92.

Bacskai-Atkari, Julia. "The Hungarian Verse Novel in a Cross-Cultural Perspective." Worlds of Hungarian Writing: National Literature as Intercultural Exchange. Ed. András Kiséry, Zsolt Komáromy, and Zsuzsanna Varga. Lanham: Rowman \& Littlefield, 2016. 93-106.

Bacskai-Atkari, Julia. “For a Comparative Approach to Genre History and the Verse Novel." Le Comparatisme comme approche critique - Comparative Literature as a Critical Approach. Ed. Anne Tomiche. Paris: Classiques Garnier, 2017. 397-405.

Barton, Anne. Byron: Don Juan. Cambridge: Cambridge University Press, 1992.

Barton, Anne. "Don Juan Reconsidered: The Haidée Episode." Byron. Ed. Jane Stabler. London: Longman, 1998. 194-203.

Burgess, Anthony. Byrne. London: Vintage, 2002.

Byron, Lord George Gordon. Don Juan. 1819. Ed. Jerome J. McGann. Vol. 5 of The Complete Poetical Works. By Byron. Oxford: Oxford University Press, 1986.

Christensen, Jerome. Lord Byron's Strength: Romantic Writing and Commercial Society. Baltimore and London: The Johns Hopkins University Press, 1993.

Cochran, Peter. “Don Juan and Tradition or, Little Juan's Potty." Aspects of Byron's Don Juan. Ed. Cochran. Newcastle upon Tyne: Cambridge Scholars Publishing, 2013a. 2-129.

Cochran, Peter. “From Byron's Giaour to Bizet’s Carmen, via Pushkin and Merimée.” Byron and Latin Culture: Selected Proceedings of the 37th International Byron Society Conference. Ed. Cochran. Newcastle upon Tyne: Cambridge Scholars Publishing, 2013b. 198-205.

Cronin, Richard. "The 'Historyful' and the 'History-less': Deep and Shallow Time in the Regency.” Confrontations and Interactions: Essays on Cultural Memory. Ed. Bálint Gárdos, Veronika Ruttkay, and Andrea Timár. Budapest: L’Harmattan, 2011. 341-351.

Elledge, Paul. "Chasms in Connections: Byron Ending (in) Childe Harold's Pilgrimage 1 and 2." Byron. Ed. Jane Stabler. London: Longman, 1998. 123-137.

Fischer, Hermann. Romantic Verse Narrative: The History of a Genre. Cambridge: Cambridge University Press, 1991.

Gregory, Allan. "Juvenalian Satire and Byron." Byron and Latin Culture: Selected Proceedings of the 37th International Byron Society Conference. Ed. Peter Cochran. Newcastle upon Tyne: Cambridge Scholars Publishing, 2013. 142-149.

Haslett, Moyra. Byron's Don Juan and the Don Juan Legend. Oxford: Clarendon Press, 1997. 
Manning, Peter J. “Byron's Imperceptiveness to the English Word.” Byron. Ed. Jane Stabler. London: Longman, 1998. 180-193.

Marchand, Leslie Alexis. Byron: A Portrait. London: John Murray, 1971.

Margócsy, István. “Térey János: Paulus.” 200014.1 (2002): 37-45.

McGann, Jerome. Fiery Dust: Byron's Poetic Development. Chicago and London: University of Chicago Press, 1968.

McGann, Jerome. Byron and Romanticism. Cambridge: Cambridge University Press, 2002.

Modrzewska, Mirostawa. "Pilgrimage or Revolt? The Dilemmas of Polish Byronism." The Reception of Byron in Europe. Ed. Richard A. Cardwell. London: Thoemmes Continuum, 2004. 305-315.

Pushkin, Alexander Sergeyevich. Eugene Onegin. 1825. Trans. Charles Johnston. London: Penguin, 2003.

Rawson, Claude. "Byron Augustan: Mutations of the Mock-Heroic in Don Juan and Shelley's Peter Bell the Third." Byron: Augustan and Romantic. Ed. Andrew Rutherford. London: Macmillan, 1990. 82-116.

Reiman, Donald. The Romantics Reviewed. Vol. B.4. New York: Garland, 1972.

Seth, Vikram. The Golden Gate. London: Faber and Faber, 1986.

Shears, Jonathon. "Digesting Don Juan Cantos I and II." Aspects of Byron's Don Juan. Ed. Peter Cochran. Newcastle upon Tyne: Cambridge Scholars Publishing, 2013. 130-143.

Stabler, Jane. Byron, Poetics and History. Cambridge: Cambridge University Press, 2002.

Térey, János. Paulus. Budapest: Palatinus Kiadó, 2001.

Tosi, Alessandra. Waiting for Pushkin: Russian Fiction in the Reign of Alexander I (1801-1825). Amsterdam and New York: Rodopi, 2006.

Vulliamy, Calwyn Edward. Byron. London: Michael Joseph, 1948.

Julia Bacskai-Atkari completed her dissertation in Literary Studies at the University of Hamburg in 2018. In addition, she holds a doctorate in Linguistics from the University of Potsdam (2014), where she conducted a research project as a principal investigator. Her focus in literary studies is the narrative structure of verse novels and other verse narratives, as well as the works of Byron. 